Research Article

\title{
United Nations Security Council Intervention To wards Gross Human Rights Violation of The Rohingya Ethnicity
}

\author{
Nizam Safaraz \\ Postgraduate Student, Faculty of National Security, Peace and Conflict Resolution, Universitas Pertahanan \\ Indonesia
}

\begin{abstract}
Every human being has the rights to be protected from discrimination by any party, especially the act of gross human rights violations. In order to prevent this, the Security Council has a function to secure international peace and security from threats to international peace. One of the case that is becoming an international concern is the human rights violations on Rohingya by Myanmar Military. In its implementation, the UN Security Council can intervene a country known to violate human rights of its people, however the Security Council's intervention caused a controversy that questioned the validity of the intervention by Security Council. Thus, the purpose of this research is to find out whether the situation in Myanmar is valid for the UN Security Council to carry out humanitarian interventions. Accordingly, this research also analyzes legal measures by the UN Security Council in dealing with human rights violations in Myanmar.
\end{abstract}

\section{Keyword: Human Rights, Humanitarian Intervention, Rohingya, UN Security Council}

\section{Introduction}

About 500,000 people of Rohingya ethnicity have fled Myanmar to neighboring countries due to torture, rape, and killing of Myanmar security forces against the Rohingya. ${ }^{1}$ As a stateless minority, this ethnic group has experienced prolonged discrimination since 1948 in Myanmar through restrictions on rights. ${ }^{2}$ The massacres were systematically intensified in the aftermath of the military coup in $1962 .{ }^{3}$ The Tatmadaw (Myanmar Armed Forces), led by General Ne Win seized power from the elected civilian government in 1962. General Ne Win seems to harbor strong animosity towards the Rohingya ethnic group. This can be seen from the military operations under General Ne Win's command that targeted the Rohingya ethnic group. 4

In accordance with Article 3 of Burma Citizenship Law 1982, stated that:

"Nationals such as the Kachin, Kayah, Karen, Chin, Burman, Mon, Rakhine or Shan and ethnic groups as have settled in any of the territories included within the State as their permanent home from period anterior to 1185 B.C., 1823 A.D. are Burma citizens."

Based on this article, Rohingya ethnic groups should have Myanmar citizenship, because since the beginning, a group of Muslims have lived in the northern Rakhine region and call themselves Rohingya. ${ }^{5}$ However, Article 4 of the Burma Citizenship Law 1982 states that "the Council of State may decide

\footnotetext{
${ }^{1}$ Michal Saliternik, " Myanmar's Rohingya Crisis and the Need for a Regional Response to Statelessness in Southeast Asia". https://www.ejiltalk.org/the-rohingya-crisis-and-the-need-for-a-regional-response-to-statelessness-in-southeast asia/\#more-15640 on May 1st 2021.

${ }^{2}$ Ibid.

${ }^{3}$ Michael F. Martin, "Burma's Brutal Campaign Against the Rohingya" Congressional Research Service, 2017, pg. 4.

${ }^{4}$ Ibid.

5 Jacques P Leider, " Rohingya: The name, the movement, the quest for identity." https://www.academia.edu/7994939/_Rohingya_The_name_the_movement_the_quest_for_identity._Yangon_2013 on May 1st 2021.
} 
whether any ethnic group is national or not". Myanmar insists that there is no such ethnic group as the Rohingya in Rakhine state, claiming instead that they are "illegal immigrants" from Bangladesh. ${ }^{6}$ The Myanmar government refuses to recognize the Rohingya as citizens, effectively rendering the majority of them stateless. ${ }^{7}$

However, this situation continued until the major crisis experienced by the Rohingya in 2017. More than 650,000 ethnic Rohingya have fled from violence and persecution in Rakhine. ${ }^{8}$ This brings the total number of Rohingya refugees in Bangladesh to over 900,000. The Bangladesh government in Cox's Bazar has difficulty handling the arriving Rohingya refugees, due to constraints on funding, poor coordination and planning due to the high increase in the number of refugees. ${ }^{9}$

\section{Method}

This study uses a qualitative research model. Qualitative research aims to obtain a complete picture of something according to the human perspective being studied. Qualitative research deals with the ideas, perceptions, opinions, or beliefs of the person being studied; they cannot be measured by numbers. ${ }^{10}$

From the above opinion, it can be seen that qualitative research is research that is used if the research factors cannot be quantified or cannot be calculated so that variables cannot be expressed in numbers such as perceptions and opinions. The qualitative research steps that the researcher uses are divided into three steps. The first step is to consider and select a research topic, state the problem and formulate theory, facts and predecessor analysis based on secondary data. The second step is to develop a framework for completing the research. The third step is collecting data, completing research, focused activities, narrowing data collection and conducting analysis for discussion and conclusions from the collected library data.

In this study, the approach method used is the normative juridical research method, so the research is focused on examining the application of the rules or norms in positive law by examining secondary data as the basic material for research by conducting a search of regulations and literatures related to the problem. ${ }^{11}$

\section{Conceptual Framework}

\section{Gross Violation of Human Rights}

Gross violation of human rights have a wide impact both at the national and international levels which constitute a feeling of insecurity for both individuals and society, so it is necessary to immediately restore it in realizing the rule of law to achieve peace, order, peace, justice and public welfare. ${ }^{12}$ Gross violation of human rights are also interpreted as an offense that leads to violations, as a means for the achievement of government policies carried out in a certain quantity and in a way to create a situation for life, the right to personal integration or the right to personal freedom of the population as a whole are constantly being violated or threatened. ${ }^{13}$

However, until now there has been no standard definition of gross violation of human rights. Judging from the various used terms, there are those that use the term gross and systematic violations, the most serious crimes, gross violations, grave violations and so on. ${ }^{14}$ Under the Rome Statute 1998, gross violation of

\footnotetext{
${ }^{6}$ Amnesty International, "Why Rohingya refugees shouldn't be sent back to Myanmar". https://www.amnesty.org/en/latest/news/2018/11/why-rohingya-refugees-shouldnt-be-sent-back-to-myanmar/ on May $2^{\text {nd }} 2021$. ${ }^{7}$ Ibid.

${ }^{8}$ Caitlin Wake, "The Rohingya Crisis: Making the Transition from emergency to longer term development", Humanitarian Policy Group, 2018, pg. 2.

${ }^{9}$ Ibid.

${ }^{10}$ Sulistyo Basuki, Metode Penelitian, Jakarta: Wedatama Widya Sastra, 2006, pg. 17.

${ }^{11}$ Soerjono Soekanto \& Sri Mamudji, Penelitian Hukum Normatif(Suatu Tinjauan Singkat), Jakarta: Rajawali Pers, 2001, pg. 1314.

${ }^{12}$ R. Wiyono, Pengadilan Hak Asasi Manusia, Jakarta: Kencana, 2006, pg. 170.

${ }^{13}$ Cecilia Medina Quiroga, The Battle of Human Right: Gross, Systematic Violations dalam Muladi, Demokratisasi, Hak Asasi Manusia dan Reformasi Hukum di Indonesia, Jakarta: The Habib Center, 2002, pg. 75.

${ }^{14}$ Supriady Widodo Eddyono, Praperadilan di Indonesia: Teori, Sejarah, dan Praktiknya, Jakarta: Institute for Criminal Justice Reform, 2014, pg. 12.
} 
human rights are listed as the most serious crimes that are of concern to the international community in their prevention. ${ }^{15}$ Although it does not provide a detailed definition, Article 5 of the Rome Statute 1998 explains that acts that are defined or considered as gross human rights violations are genocide, crimes against humanity, war crimes and crimes of aggression. ${ }^{16}$

Gross violation of human rights is an extra ordinary crime and has a wide impact both at the national and international levels which constitutes a feeling of insecurity for both individuals and society, so it is necessary to immediately restore it in realizing the rule of law to achieve peace, order, peace, justice, and public welfare. ${ }^{17}$ There is no doubt that gross human rights violations can be said to be an international problem. Serious human rights violations are no longer an internal problem for the country concerned. ${ }^{18}$ Thus, actions such as investigations, discussions, and condemnation of gross human rights violations in a country are valid. ${ }^{19}$

\section{Forms of Gross Violation of Human Rights}

According to the 1998 Rome Statute, there are four actions that are said to be the most serious crimes, namely genocide, crimes against humanity, war crimes and crimes of aggression. ${ }^{20}$ But this discussion will only discuss two crimes, namely genocide and crimes against humanity. Because these two crimes are relevant to be discussed with gross human rights violations against the Rohingya ethnicity. The crimes that constitute gross human rights violations against the Rohingya can be classified as follows:

\subsubsection{Genocide}

Genocide is a crime that first attracted international attention, namely the creation of the Genocide Convention in 1948 as an implication of the Nuremberg trials which tried Nazi leaders who systematically attacked groups of the Jewish community. ${ }^{21}$ Article 1 of the convention states that genocide committed in times of peace or war is a crime committed under international law. Genocide is a crime committed with the intention of destroying national, ethnic, racial or religious groups in whole or in part, as follows: ${ }^{22}$
a. $\quad$ Killing members of the group;
b. Causing serious bodily or mental harm to members of the group;
c. Deliberately inflicting on the group conditions of life calculated to bring about its physical destruction in whole or in part;
d. Imposing measures intended to prevent births within the group;
e. Forcibly transferring children of the group to another group.

\subsubsection{Crimes Against Humanity}

According to Article 7 paragraph (1) of Rome Statute 1998, crimes against humanity means any of the following acts when committed as part of a widespread or systematic attack directed against any civilian population, with knowledge of the attack: ${ }^{23}$
a. Murder;
b. Extermination;
c. Enslavement;
d. Deportation or forcible transfer of population;

\footnotetext{
${ }^{15}$ Otto Triffterer, Commentary on the Rome Statute of the International Criminal Court, Germany: Nomos Verlagsgesellschaft, 1999.pg. 100 .

${ }^{16}$ Ibid.

${ }^{17}$ F.Budi Hadirman, Terorisme Definisi, Aksi dan Regulasi, Jakarta: Imprasial, 2003, pg. 63.

${ }^{18}$ Peter Malanzcuk, Modern Introduction to International Law, New York: Routledge, 2002, pg. 221.

${ }^{19}$ Ibid.

${ }^{20}$ Article 5, Rome Statute 1998.

${ }^{21}$ Geoffrey Robertson, Crimes Against Humanity: The Struggle for Global Justice, New York: The New Press, 2000, pg 281.

${ }^{22}$ Article 2, Convention on the Prevention and Punishment of the Crime of Genocide 1948.

${ }^{23}$ Article 7 paragraph (1) Rome Statute 1998
} 
Nizam Safaraz et. al/ United Nations Security Council Intervention To wards Gross Human Rights Violation of The Rohingya Ethnicity

e. Imprisonment or other severe deprivation of physical liberty in violation of fundamental rules of international law;

f. Torture;

g. Rape, sexual slavery, enforced prostitution, forced pregnancy, enforced sterilization, or any other form of sexual violence of comparable gravity;

h. Persecution against any identifiable group or collectivity on political, racial, national, ethnic, cultural, religious, gender as defined in paragraph 3, or other grounds that are universally recognized as impermissible under international law, in connection with any act referred to in this paragraph or any crime within the jurisdiction of the Court;

i. $\quad$ Enforced disappearance of persons;

j. $\quad$ The crime of apartheid;

k. Other inhumane acts of a similar character intentionally causing great suffering, or serious injury to body or to mental or physical health.

\section{The Powers of United Nations Security Council}

The UN Security Council is authorized by the UN Charter to maintain international peace and security by resolving these disputes in accordance with the rules of the UN Charter. ${ }^{24}$ All UN members must approve and implement UN Security Council decisions. ${ }^{25}$ Whereas other UN organs are only limited to providing recommendations to member countries, only the UN Security Council has the power to make decisions which are then obliged to be implemented by member countries under the UN Charter. ${ }^{26}$ These decisions or these UN Security Council resolutions must be implemented by all the actors involved. ${ }^{27}$

\subsubsection{Protecting International Peace and Security}

Article 34 of the UN Charter states that the UN Security Council has the authority to carry out investigations into situations that are considered to threaten international peace and security, but this does not mean that exclusive access is given to the UN Security Council as the only organ that can carry out investigations. ${ }^{28}$ Chapter VI of the 1945 UN Charter deals with peaceful conflict management means, if there is no outcome aimed at creating peace, the Security Council is given the authority under chapter VII of the 1945 UN Charter in determining whether or not there is a threat, violation or aggression against peace. ${ }^{29}$ Article 39 of the 1945 UN Charter authorizes the UN Security Council to impose sanctions with a broad interpretation in accordance with its powers. ${ }^{30}$

Although the threat to international peace and security is not given clear criteria by the 1945 UN Charter, in its development, in addition to the existence of a conflict between two countries which is considered a threat to international peace and security ${ }^{31}$, violent conflict within a country can also be said to be a threat against international peace and security. ${ }^{32}$ This is based on Security Council Resolution 713 which states that there is a threat to international peace and security in the Yugoslav internal conflict in 1991 between the Yugoslav governments and Slovenia and Croatia which recently declared their independence. ${ }^{33}$ In determining whether there is a threat or not, it can be interpreted broadly as long as there is agreement among the permanent members of the UN Security Council. ${ }^{34}$

\subsubsection{Consider and Recommend Dispute Resolution Procedures}

\footnotetext{
${ }^{24}$ Article 39, United Nations Charter 1945.

${ }^{25}$ Article 25, United Nations Charter 1945.

${ }^{26}$ SweMUN, "Security Council: Burundi Counsultations", United Nations Association of Sweden, 2016, pg. 4. https://fn.se/wpcontent/uploads/2016/06/Security-Council-Burundi-SweMUN.pdf on May 2nd 2021.

27 Ibid.

${ }^{28}$ Bruno Simma, The Charter of The United Nations : A Commentary, New York: Oxford University Press, $1995 . p g .515$.

${ }^{29}$ Article 39, United Nations Charter 1945.

${ }^{30}$ Bruno Simma, Op.Cit, pg. 607.

${ }^{31}$ United Nations Security Council, United States of America: revised draft resolution, S/10446/Rev. 1, 12 th December 1971.

${ }^{32}$ Bruno Simma, Op.Cit, pg . 611.

${ }^{33}$ Resolution adopted by Security Council, 3009th meeting. (S/RES/ 713, 25th September 1991), pg. 2.

${ }^{34}$ Bruno Simma, Op.Cit, pg. 612.
} 


\section{Nizam Safaraz et. al/ United Nations Security Council Intervention To wards Gross Human Rights Violation of The Rohingya Ethnicity}

In chapter VI of the Charter of the United Nations, the UN Security Council is empowered to make recommendations on dispute resolution procedures. The steps the Security Council can take are as follows:

a. $\quad$ Call all parties to use peaceful means if the situation jeopardizes international peace and security; ${ }^{35}$

b. Recommend dispute resolution mechanisms; ${ }^{36}$

c. Recommend appropriate procedures or methods for dispute resolution, and consider submitting legal disputes to the International Court of Justice ("ICJ").

In chapter VII of the UN Charter, the UN Security Council can resolve disputes using non-military and military mechanisms. Article 39 of the 1945 UN Charter refers to Articles 41 and 42 to implement the sanctions to be imposed by the UN Security Council. In other words, if the criteria of Article 39 have been fulfilled, the UN Security Council can take decisive steps to protect international peace and security under Articles 41 and 42 of the 1945 UN Charter.

\section{Result and Discussion}

\section{The Legality of Gross Human Rights Violations in Myanmar}

Humanitarian intervention in general is an effort to prevent or stop serious human rights violations with certain powers (diplomatic and military) in a country, either with or without the consent of countries experiencing internal conflicts. ${ }^{38}$ When a humanitarian problem occurs in a country that is a gross violation of human rights, the international community is justified in taking an intervention. ${ }^{39}$

J.G Starke in his statement, believes that intervention is not necessarily an act against the law, for certain reasons, namely: ${ }^{40}$

a. Collective interventions defined in the Charter of the United Nations; ${ }^{41}$

b. To protect the rights and interests of other citizens; ${ }^{42}$

c. $\quad$ Self defense ${ }^{43}$

d. If the country to be intervened is deemed to have committed serious international violations. ${ }^{44}$

Article 4 of the Burma Citizenship Law 1982 stipulates that the Rohingya ethnicity is not recognized as an official ethnicity from Myanmar, because the government has the authority to decide whether an ethnicity can be considered Myanmar citizens, but the fact is Myanmar insists that there is no group like the Rohingya Rakhine states, on the other hand, claim they are "illegal immigrants" from Bangladesh. ${ }^{45}$ They refuse to recognize them as citizens, effectively rendering the Rohingya stateless. ${ }^{46}$ The loss of Rohingya ethnic citizenship will certainly affect the condition of children born in this ethnicity. Myanmar must ensure the implementation of the above rights in accordance with the laws of the respective countries and their obligations under the relevant international instruments in this field, especially if the child is declared stateless. On the other hand, the Government of Myanmar has ratified the 1989 Convention on the Rights of the Child in $1991^{47}$ and is obliged to grant citizenship status to children born in Myanmar who are declared stateless in accordance with Article 7 of Convention on the Rights of the Child 1991.

Myanmar has ratified several international conventions related to human rights. Based on this action, Myanmar accepts an international legal obligation to comply with the convention's rules in good faith and

\footnotetext{
${ }^{35}$ Article 33 ayat (2), United Nations Charter 1945.

${ }^{36}$ Article 36 ayat (1), United Nations Charter 1945.

${ }^{37}$ Article 36 ayat (3), United Nations Charter 1945.

${ }^{38}$ Pierre Laberge, "Humanitarian Intervention: Three Ethical Positions" Ethics \& International

Affairs, Vol. 9, 1995, pg. 15

${ }^{39}$ Ibid.

${ }^{40}$ J.G. Starke, Pengantar Hukum Internasional, Jakarta: Penerbit Sinar Grafika,1988.pg. 137

${ }^{41}$ Ibid.

42 Ibid.

${ }^{43}$ Ibid.

${ }^{4}$ Ibid.

${ }^{45}$ Amnesty International, "Why Rohingya refugees shouldn't be sent back to Myanmar", Loc.Cit.

46 Ibid.

${ }^{47}$ Global Justice Center, "Myamar/Burma's Binding Obligations Under International Law", Human Rights Through the Rule of Law, 2012,pg.4, http://globaljusticecenter. net/documents/BindingObligations.pdf on May $2^{\text {nd }} 2021$
} 
cannot use its national law as an excuse to violate the obligations of international conventions that have been previously ratified, this is based on Article 27 of Vienna Convention on the Law of Treaties 1969. ("VCLT 1969"). The following are international conventions related to human rights that have been ratified by Myanmar, including ${ }^{48}$ :

a. International Covenant on Civil and Political Rights;

b. $\quad$ Convention against Torture and Other Inhuman or Degrading Treatment or Punishment;

c. $\quad$ Convention for the Protection of All Persons from Enfroced Disapperance;

d. International Covenant on Economic, Social and Cultural Rights;

e. Convention on the Prevention and Punishment of the Crime of Genocide;

f. International Convention on the Elimination of All Forms of Racial Discrimination;

g. $\quad$ Convention on the Elimination of All Forms of Discrimination against Women;

$\mathrm{h}$. International Convention for the Suppression of the Traffic in Women and Children;

i. $\quad$ Convention on the Rights of Persons with Disabilities;

j. $\quad$ Convention on the Rights of the Child;

k. Optional Protocol to the Convention on the Rights of the Child on the involvement of children in armed conflict.

Based on Article 26 of VCLT 1969, a country that has ratified and commited to comply with an international convention reflects that the country is willing to implement the contents of the convention in good faith. If a country does not fulfilled the provisions in accordance with the relevant international convention, then that country is deemed to have violated its legal obligations under the convention. ${ }^{49}$ Referring to Article 27 of the VCLT 1969, a state cannot argue its internal legal provisions to justify its failure to carry out its obligations under international conventions. The violation of the rules of a convention also does not merely cause the country to end the agreement unilaterally. ${ }^{50}$ If a state violates its obligations under an international convention, that state has an obligation to remedy the consequences of its actions with reasonable effort, and this obligation is not required to be stated in the violated international convention. ${ }^{51}$ Based on these facts, we can argue that Myanmar has clearly violate international law due to its behavior towards the Rohingya ethnicity.

Myanmar's actions against the Rohingya people violate many fundamental rights of the Rohingyan, including the rights provided under the ICCPR. The Myanmar authorities have engaged in a deliberate campaign to make it difficult for the Rohingya in a restricted form of self-identification. ${ }^{52}$ The government has made it difficult for Rohingya people to register their newborn on the family card. ${ }^{53}$ Apart from discrimination against newborns, in northern Rakhine State, Rohingyan who are not at home at the time of the annual population census are at risk of being deleted from official records. One consequence of this campaign is that, it is nearly impossible for Rohingya who have left Myanmar to return to their homes. This has continued into 2017 which has driven more than 700,000 Rohingya to flee to Bangladesh, where they are living in refugee camps in dire conditions. ${ }^{54}$

The form of discrimination that has developed for a very long time has also led to many acts demeaning the Rohingyan, even to the ethnic cleansing phase. Other serious human rights violations, namely genocide were also carried out by Myanmar Military, which had committed acts that caused the extinction of all or part of the Rohingya ethnic, such as killing members of the Rohingya ethnic group, destroying the body or mind of the Rohingya ethnic members and deliberately causing physical damage in whole or in part

\footnotetext{
${ }^{48}$ United Nations Human Rights Office of the High Commissioner, "Ratification Status for Myanmar", 2021, https://tbinternet.ohchr.org/ layouts/15/TreatyBodyExternal/Treaty.aspx?CountryID=119\&Lang=EN on May 2 nd 2021 .

${ }^{49}$ Curtis A. Bradley, "Violation of Treaty Obligation”, American Journal of International Law, Vol. 29, 2016, pg. 1077.

${ }^{50}$ Ibid.

${ }^{51}$ Publication of Permanent Court of International Justice, “Collection of Judgements, Series A, No 9", International Court of Justice, 1927.

${ }^{52}$ Amnesty International, " Myanmar: Rohingya trapped in dehumanising apartheid regime".

https://www.amnesty.org/en/latest/news/2017/11/myanmar-rohingya-trapped-in-dehumanising-apartheid-regime/ on May $1^{\text {st }}$

2021.

53 Ibid.

54 Ibid.
} 
towards the Rohingyan. ${ }^{55}$

The fact-finding mission states that the actions that have been carried out by Myanmar Military are considered as genocide, because the actions taken were aimed at eliminating the Rohingya ethnicity who are one of the groups protected from the 1948 Genocide Convention. ${ }^{56}$ What is interesting is that Myanmar has ratified the 1948 Genocide Convention in $1956^{57}$, which means that Myanmar clearly violates Article 2 of the 1948 Genocide Convention.

Apart from genocide, Myanmar also conduct an act that can be classified as gross human rights violations, one of which is crimes against humanity. The crimes against humanity experienced by the Rohingya include mass and arbitrary killings, rape, torture, confiscation of land and buildings, forced labor and slavery, forced relocation, and extortion. ${ }^{58}$ This act of clearly violates article 7 of the 1998 Rome Statute and can be classified as most serious crimes according to the 1998 Rome Statute. Therefore, we argue that the situation in Myanmar could and should be classified as a gross violation of human rights.

\section{Humanitarian Intervention According to Chapter VII of the 1945 United Nations Charter}

Non-military intervention against Myanmar can be carried out by the UN Security Council by issuing a UN Security Council Resolution commanding Myanmar to establish an ad-hoc human rights court in Myanmar with the aim of restoring human rights violations that have occurred. The establishment of a human rights court within the national scope has also been carried out by the UN Security Council in Indonesia. ${ }^{59}$ The background of the establishment of a human rights court in Indonesia is the insistence of the UN Security Council through its resolution on Indonesia to immediately resolve the conflict in Timor-Timor. ${ }^{60}$ This resolution placed Indonesia under international pressure, thus urging Indonesia to immediately resolve this conflict. ${ }^{61}$ Indonesia then established a human rights court through government policy and succeeded in showing positive results, Indonesia could show the UN that the East Timor problem could be resolved by Indonesia itself, through the Indonesian legal system, and without foreign interference. ${ }^{62}$

If the establishment of a human rights court is deemed impossible due to the response of the Myanmar government that is not willing to resolve this issue, the UN Security Council can establish a hybrid tribunal court to punish perpetrators of serious human rights crimes in Myanmar. The UN Security Council can implement binding Security Council Resolutions to create a hybrid tribunal that combines national and international elements such as the ECCC in Cambodia. This hybrid tribunal, which consists of Myanmar national and international organs, has the authority to judge according to the urgency of the gross human rights violations that have occurred, especially with the jurisdiction of genocide based on the 1948 Genocide Convention, crimes against humanity based on the 1998 Rome Statute and protection of citizenship status based on the 1961 Convention on the Reduction of Statelessness.

Another alternative dispute resolution mechanism that may be implemented by the UN Security Council is the establishment of an ad-hoc international criminal tribunal based on the UN Security Council Resolution which is in accordance with chapter VII of the UN Charter 1945 due to threats to international peace and security. An ad-hoc international criminal court has authorized the UN Security Council to take full control

\footnotetext{
${ }^{55}$ Human Rights Council, Report of the independent international fact-finding mission on Myanmar, (A/HRC/39/64, 39th session, 28th September 2018)

${ }^{56}$ Human Rights Council, Report of the independent international fact-finding mission on Myanmar, (A/HRC/39/64, 39th session, 28th September 2018).

${ }^{57}$ Global Justice Center, Op.Cit,pg.4.

58 Amnesty International, "My World is Finished", Amnesty International Ltd, 2017, pg. 9.

${ }^{59}$ Romli Atmasasmita, "Human Rights and Human Rights Courts in the Context of Permanent International Courts", one day seminar of Adjudication of Human Rights Violation by A National, Regional or International Human Rights Court", Yayasan Hak Asasi Manusia, Demokrasi dan Supremasi Hukum, 2001, pg. 18.

${ }^{60}$ Resolution adopted by Security Council, 3998th meeting, (S/RES/1236, 7th May 1999), pg. 2.

${ }^{61}$ Human Rights Watch, "East Timor", https://www.hrw.org/legacy/wr2k1/asia/etimor.html on May $2^{\text {nd }} 2021$.

62 The Indonesian National Commission on Human Rights, Annual Report 1999, Jakarta : The Indonesian National Commission on Human Rights, 2000, pg. 38.
} 
of the settlement of disputes that occurred in Myanmar, because Myanmar is considered unwilling to resolve various cases of gross human rights violations that have occurred against the Rohingya ethnicity. ${ }^{63}$

If non-military intervention has not yielded adequate results, then military intervention can be implemented through Article 42 of the 1945 UN Charter by deploying UN Peacekeeping Force inside the territory of Myanmar which aims to maintain security and restore human rights violations that have occurred. Through the UN Security Council Resolution, a UN peacekeeping force can be formed and demoted to Myanmar territory under the mandate of the UN Security Council. The mandate given to these troops is devoted to facilitating the process of protecting the Rohingya ethnic group from returning to their homes and the protection of humanitarian assistance aimed at ethnic Rohingya by the international community.

\section{Humanitarian Intervention Implementation Through Coordination Between the UN Security Council and the International Criminal Court}

Another mechanism that can be used by the UN Security Council is dispute resolution through the International Criminal Court ("ICC"). The ICC is a judicial institution established to resolve gross human rights violations. The ICC only has jurisdiction over the most serious crimes of international concern, which include genocide, crimes against humanity, war crimes and crimes of aggression. ${ }^{64}$ The main requirement for the ICC jurisdiction to be enacted is that in the event that the crime committed occurs within the territory of a party to the Rome Statute or the nationality of the perpetrator is a country that is a party to the Rome Statute. ${ }^{65}$

The ICC prosecutes individuals, not groups or countries. Any individual suspected of having committed a crime within the jurisdiction of the ICC can be brought before the ICC. No one can be exempted from prosecution, regardless of what position he was during when the crime was committed. Heads of State or government, ministers or members of parliament are inseparable from the responsibility and prosecution of the ICC. In some circumstances, a person who is in charge of authority may even be held responsible for crimes committed by those acting under his orders.

Between the ICC and the UN Security Council, there are trigger mechanisms that can activate the jurisdiction of the ICC. ${ }^{66}$ According to Article 13 of the Rome Statute, the ICC can exercise its jurisdiction in the event that the prosecutor has been granted authority through:

a. The UN Security Council acting under the authority of chapter VII of the UN Charter; ${ }^{67}$

b. States parties to the Rome Statute; ${ }^{68}$

c. The prosecutor's own initiative (proprio motu) is based on information received from certain sources. ${ }^{69}$

Based on the various possible legal remedies that can be made by the UN Security Council to solve the gross human rights violations towards the Rohingya etnichity, the author conclude that the most ideal mechanisms to use are dispute resolution efforts through the ICC and the implementation of the UN Peacekeeping force to protect the Rohingyan. Unlike the local human rights tribunal, ad-hoc tribunal and hybrid tribunal, the ICC is an independent and permanent court based on an international treaty, namely the 1998 Rome Statute. The ICC has clear and appropriate adjudicatory powers to punish perpetrators of genocide crimes and crimes against humanity in Myanmar. The author argues that there is no urgency for the UN Security Council to form a new judiciary because of the role of the ICC. Apart from punishing the perpetrators of gross human rights violations, other mechanisms are also needed to maintain the security of the Rohingya so that this

\footnotetext{
${ }^{63}$ United Nations, The Blue Helmets: A Review of United Nations Peacekeeping, New York: United Nations Department of Public Information, 1991, pg. 4.

${ }^{64}$ Article 5 ayat (1) ,Rome Statute 1998.

${ }^{65}$ Article 12 ayat (2), Rome Statute 1998.

${ }^{66}$ Antonio Cassese, International Criminal Law, New York: Oxford University Press, 2003, pg. 733.

${ }^{67}$ Article 13, Rome Statute 1998

${ }^{68}$ Ibid.

${ }^{69}$ Ibid.
} 
alarming situation can be solved. The UN peacekeeping force is needed with the urgency to return Rohingya refugees to their homes in Myanmar and to maintain the continuity of humanitarian assistance for the Rohingya ethnicity.

\section{Conclusion}

The Rohingya ethnic conflict in Myanmar has met the indicators of a situation that threatens international peace and security, based on the gross human rights violations committed by the Myanmar military. Therefore, the UN Security Council can carry out humanitarian intervention against Myanmar strictly based on the powers it has under Chapter VII of the 1945 UN Charter and the UN Security Council should immediately issue a UN Security Council Resolution stating that this case is a situation that threatens international peace and security and refer this case of Rohingya to the ICC so that perpetrators of crimes against serious human rights violations towards the Rohingya ethnicity can be brought to justice. In establishing the UN Peacekeeping Force, the UN Security Council must pay attention to the ongoing supervision of the UN peacekeeping force in the process of returning the Rohingya to Myanmar and providing humanitarian assistance to the Rohingya so that this situation of gross human rights violations can be restored as soon as possible.

\section{References}

\section{Books}

1. Cassese, Antonio, International Criminal Law, New York: Oxford University Press, 2003.

2. Cecilia, Medina Quiroga, The Battle of Human Right: Gross, Systematic Violations dalam Muladi, Demokratisasi, Hak Asasi Manusia dan Reformasi Hukum di $\quad$ Indonesia, Jakarta: The Habib Center, 2002.

3. Hadirman, F. Budi, Terorisme Definisi, Aksi dan Regulasi, Jakarta: Imprasial, 2003.

4. Ibrahim, Johnny Teori dan Metodologi Penelitian Hukum Normatif, Malang: Bayumedia Publishing, 2006.

5. Kashim, Ifdal Prinsip-prinsip Van Boven Mengenai Korban Pelanggaran HAM Berat, Jakarta: ELSAM, 2002.

6. Malanzcuk, Peter, Modern Introduction to International Law, New York: Routledge, 2002.

7. Robertson, Geoffrey, Crimes Against Humanity: The Struggle for Global Justice, New York: The New Press, 2000,

8. Simma, Bruno, The Charter of The United Nations : A Commentary, New York: Oxford University Press, 1995.

9. Soekanto, Soerjono, Penelitian Hukum Normatif (Suatu Tinjauan Singkat), Jakarta: Rajawali Pers, 2001.

10. Supriady Widodo Eddyono, Praperadilan di Indonesia: Teori, Sejarah, dan Praktiknya, Jakarta: Institute for Criminal Justice Reform, 2014.

11. Starke, J.G, Pengantar Hukum Internasional, Jakarta: Penerbit Sinar Grafika,1988.

12. The Indonesian National Commission on Human Rights, Annual Report 1999, Jakarta : The Indonesian National Commission on Human Rights, 2000.

13. Triffterer, Otto, Commentary on the Rome Statute of the International Criminal Court, Germany: Nomos Verlagsgesellschaft, 1999.

14. United Nations, The Blue Helmets: A Review of United Nations Peacekeeping, New York: United Nations Department of Public Information, 1991.

15. Wiyono, R. Pengadilan Hak Asasi Manusia, Jakarta: Kencana, 2006.

\subsection{Academic Papers}

14. Amnesty International, "My World is Finished", Amnesty International Ltd, 2017.

15. Bradley, Curtis A. "Violation of Treaty Obligation", American Journal of International Law, Vol. 29, 2016, pg. 1077. 
Nizam Safaraz et. al/ United Nations Security Council Intervention To wards Gross Human Rights Violation of The Rohingya Ethnicity

16. Laberge, Pierre "Humanitarian Intervention: Three Ethical Positions" Ethics \& International Affairs, Vol. 9, 1995.

17. Martin, Michael F "Burma's Brutal Campaign Against the Rohingya" Congressional Research Service, 2017.

18. Romli Atmasasmita, "Human Rights and Human Rights Courts in the Context of Permanent International Courts", Yayasan Hak Asasi Manusia, Demokrasi $\quad$ dan Supremasi Hukum, 2001.

19. Wake, Caitlin "The Rohingya Crisis: Making the Transition from emergency to longer term development", Humanitarian Policy Group, 2018.

\subsection{International Conventions}

20. Convention on the Prevention and Punishment of the Crime of Genocide 1948.

21. Convention on the Rights of the Child 1989.

22. Rome Statute 1998.

23. United Nations Charter 1945.

24. Vienna Convention on the Law of Treaties 1969.

\subsection{Documents and Reports}

25. Human Rights Council, Report of the independent international fact-finding mission on Myanmar, (A/HRC/39/64, 39th session, 28th September 2018)

26. Human Rights Council, Report of the independent international fact-finding mission on Myanmar, (A/HRC/39/64, 39th session, 28th September 2018).

27. Publication of Permanent Court of International Justice, "Collection of Judgements, Series A, No 9", International Court of Justice, 1927.

28. Resolution adopted by Security Council, 3998th meeting, (S/RES/1236, 7th May 1999).

29. Resolution adopted by Security Council, 3009th meeting. (S/RES/ 713, 25th September 1991).

30. United Nations Security Council, United States of America: revised draft resolution, S/10446/Rev. 1, 12th December 1971.

\subsection{Website}

31. Amnesty International, Why Rohingya refugees shouldn't be sent back to Myanmar, <https://www.amnesty.org/en/latest/news/2018/11/why-rohingya- refugeesshouldnt-be-sent-back-to-myanmar/>.

32. Amnesty International, Myanmar: Rohingya trapped in dehumanising apartheid regime.<https://www.amnesty.org/en/latest/news/2017/11/myanmar-rohingya-rapped indehumanising-apartheid-regime/>.

33. Global Justice Center, Myamar/Burma's Binding Obligations Under International Law, <http://globaljusticecenter.net/documents/ BindingObligations.pdf $>$.

34. Human Rights Watch, East Timor, <https://www.hrw.org/legacy/wr2k1/asia/etimor.html>.

35. P. Leider, Jacques. Rohingya: The name, the movement, the quest for identity.<https://www.academia.edu/7994939/_Rohingya_The_n

ame_the_movement_the_quest_for_identity._Yangon_2013>

36. Saliternik, Michal. Myanmar's Rohingya Crisis and the Need for a Regional Response to Statelessness in Southeast Asia.< https://www.ejiltalk.org/the- $\quad$ rohingya-crisis-and-the-need-fora-regional-response-to-statelessness-in- southeastasia/\#mor e-15640>.

37. SweMUN, Security Council: Burundi Counsultations, <https://fn.se/wpcontent/uploads/2016/06/Security-Council-Burundi-Swe MUN.pdf.>.

38. United Nations Human Rights Office of the High Commissioner, "Ratification Status for Myanmar", 2021, https://tbinternet.ohchr.org/_layouts/15/TreatyBodyExternal/Treaty.aspx?CountryID=119\&Lang=E $\underline{\mathrm{N}}$ on May $2^{\text {nd }} 2021$. 
Nizam Safaraz et. al/ United Nations Security Council Intervention To wards Gross Human Rights Violation of The Rohingya Ethnicity

39. Warzone Initiatives, Rohingya Briefing Report, $<\mathrm{http}: / / \mathrm{www}$.equalrightstrust.org /ertdocumentbank/Rohingya\%20Briefing\%20Report.pdf>. 